\title{
Do the available data permit clarification of the possible dependence of Palaeozoic brachiopod generic diversity dynamics on global sea-level changes? A viewpoint
}

\author{
Dmitry A. Ruban \\ Department of Tourism, Higher School of Business, Southern Federal University, 23-ja linija Street 43, Rostov-na- \\ Donu, 344019, Russia; postal address: P.O. Box 7333, Rostov-na-Donu, 344056, Russia
}

\begin{abstract}
At a glance, progress in palaeontology and eustatic reconstructions in the past decade permits to prove or to disprove the possible dependence of Palaeozoic brachiopod generic diversity dynamics on global sea-level changes. However, the available diversity curve is of much lower resolution than the eustatic curve. This problem can be resolved by decreasing the resolution of the latter. The other restriction linked to the chronostratigraphical incompatibility of the available data allows to focus on the Middle Palaeozoic only. A series of mass extinctions and other biotic crises in the Silurian-Devonian does not allow to interpret correctly the results of direct comparison of the brachiopod generic diversity dynamics with global sea-level changes. With the available data, it is only possible to hypothesize that the eustatic control was not playing a major part in diversity dynamics of Middle Palaeozoic brachiopods. The resolution of the stratigraphic ranges of Palaeozoic brachiopods should be increased significantly, and these ranges should be plotted against the most up-to-date geologic time scale. Until this task will be achieved, it is impossible to judge about the existence of any dependence (either full or partial) of the Palaeozoic brachiopod diversity dynamics on global sea-level changes.
\end{abstract}

Keywords: brachiopods, generic diversity, sea-level changes, Silurian, Devonian

\section{Introduction}

The possible dependence of biodiversity dynamics on global sea-level (eustatic) changes has been debated for many decades (Newell, 1967; Hallam \& Wignall, 1999; Purdy, 2008; Ruban, 2010, 2013; Smith \& Benson 2013). Accumulation of new palaeontological data, as well as development of new eustatic curves allow revisiting this conundrum, which also matters for particular groups of fossil organisms and particular intervals of the geologic history. Of course, biodiversity dynamics was not necessarily controlled by eustatic changes. The possibility that global sea-level changes were unimportant or that their influence was masked by other factors (seawater oxygenation and temperature, plate tectonics, palaeoecological processes, etc.) should not be excluded. Moreover, different suprageneric taxa would have behaved differently to eustatic fluctuations. But these considerations do not preclude from direct comparison of the diversity and eustatic curves, because we can only hypothesize on whether there were any relationship between biodiversity and sea level without such an experiment. If this comparison indicates any strong relationship, the global sea-level changes should be judged important control. If not, the above-mentioned considerations should provide explanation. 
However, before judging about its possible importance of eustasy as a factor of biotic evolution, we need to understand, first of all, our ability to make correct judgements.

Palaeozoic brachiopods are suitable for the analysis of possible dependence of their genera number on global sea-level changes because of their high diversity and its rapid changes (Curry \& Brunton, 2007) and the evolution on the time interval with significant eustatic fluctuations (Johnson et al., 1985; Loydell, 1998; Johnson, 2006, 2010; Haq \& Schutter, 2008). The goal of the present brief paper is to check whether the up-to-date data permit to understand the possible dependence of Palaeozoic brachiopod generic diversity dynamics on global sea-level changes. The available palaeontological (Curry \& Brunton, 2007) and eustatic (Haq \& Schutter, 2008) data are up-to-date, and, at a glance, they can be compared easily and interpreted effectively. But is this really so? An attempt to answer this question is presented below. In other words, this paper focuses on the methodology and not on providing any final conclusion on the above-mentioned dependence. Some other fundamental questions (linked to data preparation techniques, data completeness, interpretations, etc.), which have been well documented in recent palaeontological literature (e.g., Hammer \& Harper, 2006; Ruban \& van Loon, 2008; Benton et al., 2011; Birks et al., 2012; Wolniewicz, 2012; Irmis et al. 2013; Ruban, 2013), are also not addressed below.

\section{Is it possible to make the curves of biodiversity and sea level compatible? Resolution and time scales as restrictions}

The curve presented by Curry \& Brunton (2007) depicts the generic diversity dynamics of brachiopods. It embraces the entire Palaeozoic and reveals changes in the total number of taxa at the level of stages. The curve developed by Haq \& Schutter (2008) demonstrates the global sea-level changes. It also encompasses the entire Palaeozoic, but it has a higher resolution: fluctuations as long as 1-2 Ma are shown. The noted difference in the resolution of the curves requires making them compatible. The original palaeontological data compiled in the latest edition of "Treatise on Invertebrate Paleontology" (Kaesler \& Selden, 1997-2007), which were the basis for the curve by Curry \& Brunton (2007), do not permit to depict the diversity dynamics with a higher resolution. Thus, we can only reduce the resolution of the eustatic curve. To achieve this task, the original information about the global sea-level changes (Haq \& Schutter, 2008) needs to be modified and re-calculated. The eustatic curve can be analyzed graphically so to establish the average absolute position of the sea-level for each stage of the Palaeozoic periods. For this purpose, the absolute sea-level position for 10 slices of the geologic time divided by equal intervals is established for each stage on the basis of the original graphs presented by Haq \& Schutter (2008). This permits to obtain the eustatic curve with the stage-level resolution, and it is ready for comparison with the available diversity curve. The diversity and eustatic reconstructions can be compared both qualitatively and quantitatively. The qualitative comparisons are possible via graphical comparison of the curves. The quantitative comparisons can be made with the Spearman's rank correlation coefficient (Kendall, 1970; Birks et al., 2012).

A more challenging problem is linked to chronostratigraphy. The time scale used by Haq \& Schutter (2008) generally follows the modern developments of the Palaeozoic chronostratigraphy (Gradstein \& Ogg, 2004; Gradstein et al. 2004, 2012a,b; Kaufmann, 2006; Menning et al., 2006; Ogg et al., 2008; Cocks et al., 2010; Cramer et al., 2010; see also on-line: stratigraphy.org). Unfortunately, this is not the case for the curve proposed by Curry $\&$ Brunton (2007). These authors employed regional and outdated time units for the Cambrian, the Ordovician, the Carboniferous, and the Permian, i.e., for $\sim 71 \%$ of the Palaeozoic time (most probably, there was not chance for them to find better solution). Although some time units of Curry \& Brunton (2007) can be correlated with the updated chronostratigraphical units (see on-line: stratigraphy.org) on the basis of charts presented by Menning et al. (2006), Ogg et al. (2008), and Gradstein et al. (2012b), the accuracy of such a correlation remains questionable, and it is impossible to distribute the diversity values between these updated units. Although it is generally possible to overcome this difficulty referring to the absolute time scale, which was carefully linked by Curry \& Brunton (2007) to all stages they deal with, the entire Early Palaeozoic and the entire Late Palaeozoic are excluded from the present analysis. One reason for this is as follows. If we try to employ the absolute time scale, we will need to consider the brachiopod diversity for those stages preferred by Curry \& Brunton (2008) (the available palaeontological data are linked essentially to these stages) and to re-calculate the eustatic changes according to these stages. This can be helpful for some practical purposes, but this will also result in the "return" to 
the outdated chronostratigraphical scale, which is challenging. Moreover, one should note permanent updates of the absolute time scale in the last years (Gradstein et al., 2012a, b; see also on-line: stratigraphy.org).

\section{What does the direct comparison tell?}

Attempting the direct comparison with precautions explained above, one can conclude that the total generic brachiopod diversity and the global sea level changed in a more or less similar manner in the Silurian (Fig. 1). However, the number of taxa peaked and remained relatively high already after the Sheinwoodian eustatic maximum, i.e., when the global sea level tended to fall. The situation was different in the Devonian, when the diversity peak corresponded to the Early Devonian eustatic fall and the prominent decline in the number of taxa occurred together with the eustatic rise in the Middle Devonian (Fig. 1). Considering the entire Middle Palaeozoic interval, no clear relationship between the diversity and eustatic curves is visible (Fig. 1).

These observations are confirmed by the results of the quantitative analysis. The correlation coefficient between the changes in the total brachiopod generic diversity and the absolute global sea-level changes was -0.3 (not statistically significant), which implies no relationship. The same coefficient calculated for the Silurian only is +0.8 (statistically significant), which can be interpreted as an evidence of possible dependence of the diversity dynamics on eustatic changes. However, this coefficient is -0.3 (not statistically significant) for the Devonian only. All these results disprove the full dependence of brachiopod diversity dynamics on global sea-level changes in the Middle Palaeozoic. This conclusion rejects any outstanding importance of eustatic control on diversity dynamics.

\section{Are the results of direct comparison sensible? Middle Palaeozoic biotic crises as "evil"}

Mass extinctions and other biotic crises relevant to significant (even catastrophic) palaeoenvironmental perturbations occurred through the Middle Palaeozoic, and they took place in many if not all stages of this geologic time interval (Sepkoski et al., 1981; Raup \& Sepkoski, 1982; Aldridge et al., 1993; Jeppson et al., 1995; McGhee, 1996; Walliser, 1996; Hallam \& Wignall, 1997; Jeppson \& Aldridge, 2000; House, 2002; Jeppson \& Calner, 2003; Calner, 2005a,b; Racki, 2005; Brand et al., 2006; Ogg et al., 2008; Lehnert et al., 2010; Talent, 2012; Vodrážková et al., 2013). Undoubtedly, they were able to influence on the brachiopod diversity dynamics (but this is a mere hypothesis, brachiopods might have reacted differently to the mentioned extreme events). Many possibilities (of the kind "what would occur in the absence of a given crisis?") can be supposed. And, unfortunately, it seems to be impossible to reveal the way of diversity changes if none of these mass extinctions and crises had occurred. Although many of the mentioned events were relatively short-term, the relevant biotic declines and subsequent recoveries perturbed the fossil evolution in persistent mode through the entire Middle Palaeozoic. Uncertain relationships between mass extinctions and sea-level changes (e.g., Hallam \& Wignall, 1999) should be also noted. It is likely that the documented stage-level generic diversity of brachiopods (Fig. 1) reflects the extreme events and their consequences, and this masks the diversity dependence on the global sea-level changes.

Generally speaking, the direct comparison of the curves on the Middle Palaeozoic interval is possible (with restrictions as discussed above), but not the interpretation of its results. Biotic crises look like

Fig. 1. The Middle Palaeozoic changes in the total generic brachiopod diversity and the global sea level evaluated per stages (based on the re-calculated data from Curry \& Brunton (2007) and Haq \& Schutter (2008); see text for more information)

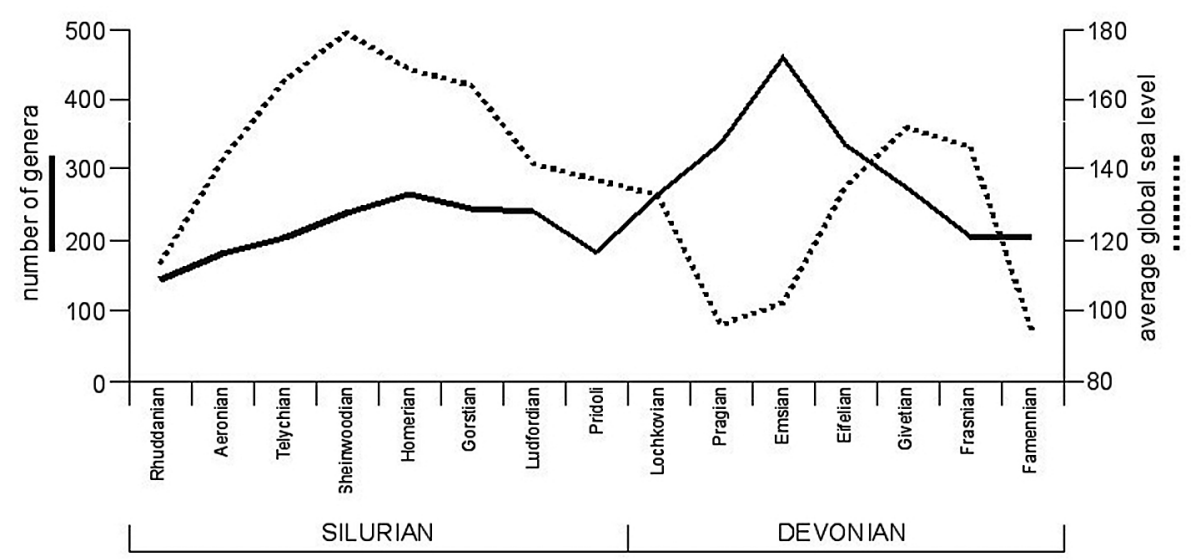


an "evil" not only for Middle Palaeozoic brachiopods and other creatures, but also for palaeobiologists trying to analyse the controls on the diversity changes. Similarly to the eustasy, comparison of the diversity dynamics with the other parameters (oxygen concentration, temperature, etc.) will face with the same difficulty because of the biotic crises. One should also note that the possible relationships between the Palaeozoic brachiopod generic diversity dynamics and the extreme events also requires high-resolution comparative analysis like that of the diversity-eustasy relationships. Moreover, there were many potentially inter-related processes and feedbacks, which could influence generic diversity, and this complex remains very difficult to unravel.

Three approaches can be suggested to avoid the problem linked to the frequent occurrence of biotic crises in the Middle Palaeozoic. Firstly, longterm trends of the diversity dynamics have to be considered. The available curves (Fig. 1) allow to delineate such trends for the Middle Palaeozoic. Generally, the brachiopod generic diversity tended to rise, whereas the global sea level tended to fall. However, these trends were evidently too weak, because of significant (and also long-term) deviations from them (e.g., the Middle-Late Devonian diversity decrease or the Early Devonian sea-level lowstand). And it is unclear how strongly the Middle Palaeozoic biotic crises affected the very diversity trend. Probably, these trends would be clarified on a longer time scale.

Secondly, it may be helpful to pay attention to the diversity dynamics and the global sea-level changes at the only "ideal" intervals, i.e., those where no biotic crises occurred. Unfortunately, this approach cannot be employed, because, as shown above, the entire Middle Palaeozoic was characterized by the "turbulent" evolution of the marine invertebrates (Sepkoski et al., 1981; Raup \& Sepkoski, 1982; Aldridge et al., 1993; Jeppson et al., 1995; McGhee, 1996; Walliser, 1996; Hallam \& Wignall, 1997; Jeppson \& Aldridge, 2000; House, 2002; Jeppson \& Calner, 2003; Calner, 2005a,b; Racki, 2005; Brand et al., 2006; Ogg et al., 2008; Lehnert et al., 2010; Talent, 2012; Vodrážková et al., 2013). There were no intervals as long as 2-3 stages without extreme events that might have affected seriously the total generic diversity of brachiopods. Probably, more possibilities can be found in the Mesozoic and/or the Cenozoic, but this is beyond the focus of this work.

Thirdly, short-term analysis, i.e., the comparison of the diversity dynamics and the global sea-level changes at the level of substages or biozones, may permit to investigate the biotic evolution between the above-mentioned catastrophic events, when possible eustatic influences are not masked by biotic crises. However, this approach faces serious challenge, namely the lack of detailed palaeontological data. In fact, the taxa descriptions in "Treatise..." (Kaesler \& Selden, 1997-2007) and the compilation by Curry \& Brunton (2007) do not provide high-resolution data. Moreover, it is unclear whether stratigraphic ranges of Middle Palaeozoic brachiopod genera can be compiled in the nearest future with the necessary precision because of various biases, uncertainties in local stratigraphy, incompatible regional stratigraphic frameworks, taxonomic errors, etc. (see also Gourvennec, 2000). At least, some original (i.e., "field") palaeontological data were not justified initially to substages or biozones, but only to stages. The desired high resolution can be achieved for only particular areas or only representative sections (Lecompte et al., 1998; Botquelen et al., 2001). On the global scale, such a short-term analysis appears to be impossible now. Fortunately, it cannot be excluded that some useful data on the high-resolution species (sic!) distribution became available at the stage of the preparation of "Treatise..." (Kaesler \& Selden, 1997-2007). Further compilation of this information may help significantly in construction of the brachiopod diversity curve necessary for the analysis of possible diversity-versus-eustasy relationships.

\section{Discussion and conclusion}

The considerations presented above imply that the available up-to-date palaeontological and eustatic data still do not permit clarification of the possible dependence of the Palaeozoic brachiopod generic diversity dynamics on the global sea-level changes. This problem can be resolved in the only case of increase in the resolution of the palaeontological data, i.e., precise outlining of stratigraphic ranges of all brachiopod genera against biozones or, better $1 \mathrm{Ma}$ intervals, and justification of these data along the updated geologic time scale developed by the International Commission on Stratigraphy (Gradstein et al., 2012b; see on-line: stratigraphy. org). Interestingly, the resolution of the available eustatic reconstruction seems to be more or less enough for the short-term analysis. Anyway, it should be added both Curry \& Brunton (2008) and Haq \& Schutter (2008) discussed in detail the possible constraints and uncertainties of the knowledge they propose.

The considerations presented in this paper are not valid for brachiopods only. The same problems matter for the diversity-versus-eustasy analysis 
of the other fossil groups (e.g., Ruban, 2013) and, probably, the entire planetary biota, as well as for the other extrinsic and intrinsic controls on the biodiversity dynamics. For instance, the prominent "greenhouse" conditions persistent during the Middle Palaeozoic (Zalasiewicz \& Williams, 2012) were superimposed and/or interrupted by glacial advances and cooling episodes (Grahn \& Caputo, 1992; Streel et al., 2000; Lehnert et al., 2006, 2010; Diaz-Martinez \& Grahn, 2007; Boucot, 2009; Elrick et al., 2009; Joachimski et al., 2009; McClung et al., 2013). One may note the correspondence of the significant diversity decline after the Emsian (Fig. 1) to the Middle Devonian cooling episode (Joachimski et al., 2009). If this cooling really resulted in the brachiopod diversity decline, this fact is not consistent with the early idea of Valentine (1968), who linked the high number of taxa to the cooling-induced differentiation of global environments (see also Mayhew et al. (2008), Ruban (2010), and Zimmer \& Emlen (2013)). However, the noted "diversity decline-cooling" correspondence may be just apparent because of the "masking" effects of the Devonian biotic crises. As in the case of the eustasy, high-resolution data would only permit final judgements.

The noted absence of the dependence evaluated with the available data (Fig. 1) and proved earlier also for some other marine fossils (Ruban, 2013) permits to formulate a working hypothesis (but nothing more than a hypothesis!) about the real unimportance of eustasy as a full biodiversity control, at least, in the Middle Palaeozoic. The true problem is not the dependence or not (either full or partial) of Palaeozoic brachiopod diversity dynamics on global sea-level changes, but serious difficulties (and, most probably, impossibility) to analyze this dependence with the available data, i.e., to prove or to disprove it.

\section{Acknowledgements}

The author gratefully thanks D. Strusz (Australia) and the other, anonymous reviewer for their constructive suggestions, the editors of 'Geologos' for technical support, as well as R.J. Aldridge (UK), A.J. Boucot (USA), G. Gourvennec (France), A. Forster (Germany), N.M.M. Janssen (Netherlands), M.E. Johnson (USA), E.G. Purdy (UK), G. Racki (Poland), W. Riegraf (Germany), A.J. van Loon (Netherlands/Poland), P.B. Wignall (UK), and many other colleagues for useful communications and/or help with literature.

\section{References}

Aldridge, R.J., Jeppson, L. \& Dorning, K.J., 1993. Early Silurian oceanic episodes and events. Journal of the Geological Society, London 150, 501-513.

Benton, M.J., Dunhill, A.M., Lloyd, G.T. \& Marx, F.G., 2011. Assessing the quality of the fossil record: insights from vertebrates. [In:] McGowan, A.J. \& Smith, A.B. (Eds): Comparing the Geological and Fossil Records: Implications for Biodiversity Studies. Geological Society, London, Special Publications 358, 63-94.

Birks, H.J.B., Lotter, A.F., Juggins, S. \& Smol, J.P. (Eds), 2012. Tracking Environmental Change Using Lake Sediments. Vol. 5. Data Handling and Numerical Techniques. Springer, Dordrecht, 745 pp.

Botquelen, A., Gorvennec, R., Loi, A. \& Le Menn, J., 2001. Relations entre les variations des assemblages benthiques emsiens et l'eustatism dans la coupe de Seillou (Massif armaricain, France). Comptes rendus de l'Académie des sciences, Paris, Sciences de la terre et des planètes 332, 45-50.

Boucot, A.J., 2009. Early Paleozoic Climates (Cambrian-Devonian). [In:] V. Gornitz (Ed.): Encyclopedia of paleoclimatology and ancient environments Springer, Dordrecht, 291-293.

Brand, U., Azmy, K. \& Veizer, J., 2006. Evaluation of the Salinic I tectonic, Cancairi glacial and Ireviken biotic events: Biochemostratigraphy of the Lower Silurian succession in the Niagara Gorge area, Canada and U.S.A. Palaeogeography, Palaeoclimatology, Palaeoecology 241, 192-213.

Calner, M., 2005a. Silurian carbonate platforms and extinction events - ecosystem changes exemplified from Gotland, Sweden. Facies 51, 584-591.

Calner, M., 2005b. A Late Silurian extinction event and anachronistic period. Geology 33, 305-308.

Cocks, L.R.M., Fortey, R.A. \& Rushton, A.W.A., 2010. Correlation for the Lower Palaeozoic. Geological Magazine 147, 171-180.

Cramer, B.D., Brett, C.E., Melchin, M.J., Mannik, P., Kleffner, M.A., McLaughlin, P.I., Loydell, D.K., Munnecke, A., Jeppsson, L., Corradini, C., Brunton, F.R. \& Saltzman, M.R., 2010. Revised correlation of Silurian Provincial Series of North America with global and regional chronostratigraphic units and $\delta^{13} \mathrm{Carb}$ chemostratigraphy. Lethaia 44, 185-202.

Curry, G.B. \& Brunton, C.H.C., 2007. Stratigraphic distribution of brachiopods. [In:] P.A. Selden (Ed.): Treatise on Invertebrate Paleontology. Part H. Brachiopoda. Revised. Vol. 6. Geological Society of America, University of Kansas, Boulder, Lawrence, 2901-3081.

Diaz-Martinez, E. \& Grahn, Y., 2007. Early Silurian glaciation along the western margin of Gondwana (Peru, Bolivia and northern Argentina): palaeogeographic and geodynamic setting. Palaeogeography, Palaeoclimatology, Palaeoecology 245, 62-81.

Elrick, M., Berkyova, S., Klapper, G., Sharp, Z., Joachimski, M. \& Fryda, J., 2009. Stratigraphic and oxygen isotope evidence for My-scale glaciation driving eustasy in the Early-Middle Devonian greenhouse world. 
Palaeogeography, Palaeoclimatology, Palaeoecology 276, 170-181.

Gourvennec, R. 2000. The evolution, radiation and biogeography of early spiriferid brachiopods. Records of the Western Australian Museum Supplement 58, 335-347.

Gradstein, F. \& Ogg, J., 2004. Geologic Time Scale 2004 why, how, and where next! Lethaia 37, 175-181.

Gradstein, F.M., Ogg, J.G., Smith, A.G., Agterberg, F.P., Bleeker, W., Cooper, R.A., Davydov, V., Gibbard, P., Hinnov, L.A., House, M.R., Lourens, L., Luterbacher, H.P., McArthur, J., Melchin, M.J., Robb, L.J., Shergold, J., Villeneuve, M., Wardlaw, B.R., Ali, J., Brinkhuis, H., Hilgen, F.J., Hooker, J., Howarth, R.J., Knoll, A.H., Laskar, J., Monechi, S., Plumb, K.A., Powell, J., Raffi, I., Rohl, U., Sadler, P., Sanfilippo, A., Schmitz, B., Shackleton, N.J., Shields, G.A., Strauss, H., Van Dam, J., van Kolfschoten, T., Veizer, J. \& Wilson, D., 2004. A Geologic Time Scale 2004. Cambridge University Press, Cambridge, 589 pp.

Gradstein, F.M., Ogg, J.G. \& Hilgen, F.J., 2012a. On the geologic time scale. Newsletters on Stratigraphy 45, 171-188.

Gradstein, F.M., Ogg, J.G., Schmitz, M. \& Ogg, G. (Eds), 2012b. The Geologic Time Scale 2012. Vols. 1-2. Elsevier, Oxford, 1176 pp.

Grahn, Y. \& Caputo, M.V., 1992. Early Silurian glaciations in Brazil. Palaeogeography, Palaeoclimatology, Palaeoecology 99, 9-15.

Hallam, A. \& Wignall, P.B., 1997. Mass Extinctions and their Aftermath. Oxford University Press, Oxford, 320 pp.

Hallam, A. \& Wignall, P.B., 1999. Mass extinctions and sea-level changes. Earth-Science Reviews 48, 217-250.

Hammer, Ø. \& Harper, D.A.T., 2006. Paleontological data analysis. Blackwell, Oxford, $351 \mathrm{pp}$.

Haq, B.U. \& Schutter, S.R., 2008. A Chronology of Paleozoic Sea-Level Changes. Science 322, 64-68.

House, M.R., 2002. Strength, timing, setting and cause of mid-Paleozoic extinction. Palaeogeography, Palaeoclimatology, Palaeoecology 181, 5-25.

Irmis, R.B., Whiteside, J.H. \& Kammerer, C.F., 2013. Non-biotic controls of observed diversity in the paleontologic record: An example from the Permo-Triassic Karoo Basin of South Africa. Palaeogeography, Palaeoclimatology, Palaeoecology 372, 62-77.

Jeppson, L. \& Aldridge, R.J., 2000. Ludlow (late SIlurian) oceanic episodes and events. Journal of the Geological Society, London 157, 1137-1148.

Jeppson, L. \& Calner, M., 2003. The Silurian Mulde Event and a scenario for secundo-secundo events. Transactions of the Royal Society of Edinburgh: Earth Sciences 93, 135-154.

Jeppson, L., Aldridge, R.J. \& Dorning, K.J., 1995. Wenlock (Silurian) oceanic episodes and events. Journal of the Geological Society, London 152, 487-498.

Joachimski, M.M., Breisig, S., Buggisch, W., Talent, J.A., Mawson, R., Gereke, M., Morrow, J.R., Day, J. \& Weddige, K., 2009. Devonian climate and reef evolution: Insights from oxygen isotopes in apatite. Earth and Planetary Science Letters 284, 599-609.
Johnson, J.G., Klapper, G. \& Sandberg, C.A., 1985. Devonian eustatic fluctuations in Euramerica. Geological Society of America Bulletin 96, 567-589.

Johnson, M.E., 2006. Relationship of Silurian sea-level fluctuations to oceanic episodes and events. GFF 128, 115-121.

Johnson, M.E., 2010. Tracking Silurian eustasy: alignment of empirical evidence or pursuit of deductive reasoning? Palaeogeography, Palaeoclimatology, Palaeoecology 296, 276-284.

Kaesler R.L. \& Selden, P.A. (Eds), 1997-2007: Treatise on Invertebrate Paleontology. Part H. Brachiopoda (Revised). Vols. 1-6. Geological Society of America, University of Kansas, Boulder, Lawrence, 560 pp. (vol. 1), 950 pp. (vols. 2-3), 807 pp. (vol. 4), 677 pp. (vol. 5), 950 pp. (vol. 6).

Kaufmann, B., 2006. Calibrating the Devonian Time Scale: A synthesis of U-Pb ID-TIMS ages and conodont stratigraphy. Earth-Science Reviews 76, 175-190.

Kendall, M.G., 1970. Rank correlation methods. Griffin, London, 202 pp.

Lecompte, S., Gourvennec, R. \& Loi, A., 1998. Communautés benthiques à Brachiopodes et variations eustatiques: exemple de la formation du Faou (Dévonien, Massif armoricain, France). Comptes rendus de l'Académie des sciences, Paris, Sciences de la terre et des planètes 327, 189-195.

Lehnert. O., Joachimski, M.M., Fryda, J., Buggisch, W., Calner, M., Jeppsson, L. \& Eriksson, M.J., 2006. The Ludlow Lau Event - another glaciation in the Silurian Greenhouse. Geological Society of America, abstracts with programs 38, 183.

Lehnert, O., Männik, P., Joachimski, M.M., Calner, M. \& Frýda, J., 2010. Palaeoclimate perturbations before the Sheinwoodian glaciation: A trigger for extinctions during the 'Ireviken Event'. Palaeogeography, Palaeoclimatology, Palaeoecology 296, 320-331.

Loydell, D.K., 1998. Early Silurian sea-level changes. Geological Magazine 135, 447-471.

Mayhew, P.J., Jenkins, G.B. \& Benton, T.G., 2008. A LongTerm Association between Global Temperature and Biodiversity, Origination and Extinction i the Fossil Record. Proceedings of the Royal Society B: Biological Sciences 275: 47-53.

McClung, W.S., Eriksson, K.A., Terry, D.O., Jr. \& Cuffey, C.A., 2013. Sequence stratigraphic hierarchy of the Upper Devonian Foreknobs Formation, central Appalachian Basin, USA: Evidence for transitional greenhouse to icehouse conditions? Palaeogeography, Palaeoclimatology, Palaeoecology 387, 104-125.

McGhee, G.R., 1996. The Late Devonian mass extinction - the Frasnian-Famennian crisis. Columbia University Press, New York, 303 pp.

Menning, M., Alekseev, A.S., Chuvashov, B.I., Davydov, V.I., Devuyst, F.-X., Forke, H.C., Grunt, T.A., Hance, L., Heckel, P.H., Izokh, N.G., Jin, Y.-G., Jones, P.J., Kotlyar, G.V., Kozur, H.W., Nemyrovska, T.I., Schneider, J.W., Wang, X.-D., Weddige, K., Weyer, D. \& Work, D.M., 2006. Global time scale and regional stratigraphic reference scales of central and West Europe, East Europe, Tethys, South China, and North Amer- 
ica as used in the Devonian-Carboniferous-Permian Correlation Chart 2003 (DCP 2003). Palaeogeography, Palaeoclimatology, Palaeoecology 240, 318-372.

Newell, N.D., 1967. Revolutions in the history of life. Geological Society of America Special Paper 89, 63-91.

Ogg, J.G., Ogg, G. \& Gradstein, F.M., 2008. The Concise Geologic Time Scale. Cambridge University Press, Cambridge, $177 \mathrm{pp}$.

Purdy, E.G., 2008. Comparison of taxonomic diversity, strontium isotope and sea-level patterns. International Journal of Earth Sciences 97, 651-664.

Racki, G., 2005. Towards understanding Late Devonian global events: few answers, many questions. [In:] D.J. Over, J.R. Morrow \& P.B. Wignall (Eds): Understanding Late Devonian and Permian-Triassic Biotic and Climatic Events: Towards an Integrated Approach, Elsevier, Amsterdam, 5-36.

Raup, D.W. \& Sepkoski, J.J., 1982. Mass extinctions in the marine fossil record. Science 215, 1501-1503.

Ruban, D.A., 2010. Do new reconstructions clarify the relationships between the Phanerozoic diversity dynamics of marine invertebrates and long term eustatic trends? Annales de Paléontologie 96, 51-59.

Ruban, D.A., 2013. The late Silurian-Middle Devonian long-term eustatic cycle as a possible control on the global generic diversity dynamics of bivalves and gastropods. Geologos 19, 193-200.

Ruban, D.A. \& van Loon, A.J., 2008. Possible pitfalls in the procedure for paleobiodiversity-dynamics analysis. Geologos 14, 37-50.

Sepkoski, J.J., Bambach, R.K., Raup, D.M. \& Valentine, J.W., 1981. Phanerozoic marine diversity and fossil record. Nature 293, 435-437.

Smith, A.B. \& Benson, R.B.J., 2013. Marine diversity in the geological record and its relationship to surviving bedrock area, lithofacies diversity, and original marine shelf area. Geology 41, 171-174.

Streel, M., Caputo, M.V., Loboziak, S. \& Melo, J.H.G., 2000. Late Frasnian-Famennian climates based on palynomorph analyses and the question of the Late Devonian glaciations. Earth-Science Reviews 52, 121-173.

Talent, J.A. (Ed.), 2012. Earth and Life. Global Biodiversity, Extinction Intervals and Biogeographic Perturbations Through Time. Springer, Dordrecht, 1100 pp.

Valentine, J.W., 1968. Climatic Regulation of Species Diversification and Extinction. Bulletin of the Geological Society of America 79, 273-276.

Vodrážková, S., Frýda, J., Suttner, T.J., Koptíková, L. \& Tonarova, P., 2013. Environmental changes close to the Lower-Middle Devonian boundary; the Basal Chotec Event in the Prague Basin (Czech Republic). Facies 59, 425-449.

Walliser, O.H., 1996. Global events in the Devonian and Carboniferous. [In:] O.H. Walliser (Ed.): Global events and event stratigraphy in the Phanerozoic. Springer, Berlin, 225-250.

Wolniewicz, P., 2012. Same taxonomic name, different species: A threat to stromatoporoid biodiversity research. Geologica Belgica 15, 236-244.

Zalasiewicz, J. \& Williams, M., 2012. The Goldilocks planet: The four billion year story of earth's climate. Oxford University Press, Oxford, 303 pp.

Zimmer, C. \& Emlen, D.J., 2013. Evolution: Making Sense of Life. Roberts and Co., Greenwood Village, 680 pp.

Manuscript received: 9 January 2014 Revision accepted: 19 March 2014 